the star through the middle of the ring or bar. This supposition, however, is shown to be erroneous. For stars of a less magnitude than $5^{\circ} 5$ there is always a detention in the apparent time of emersion, which increases with the faintness of the stars observed. The cause of the error, therefore, is physiological, and due to the occulting micrometers employed. The law regulating it having been found, the necessary corrections have been applied to the measures, thus rendering the work of greater use.

The memoir represents the work of a business man over a period of twenty years, and with an instrument having an aperture of $3 \frac{1}{4}$ inches. It contains much of interest, and will doubtless be appreciated as an important contribution to the knowledge of the stars in a cluster which is certainly one of the grandest of telescopic objects.

\section{ON THE VEGETATION OF TIBET.}

I N the May number of the Fournal de Botanique MM. Bureau and Franchet describe a number of new plants from the collections recently brought home by M. Bonvalot and Prince Henry of Orleans, and give a general summary of their character, of which the following is an abstract :-

The collection was made almost entirely in a narrow band of territory reaching from Lhassa eastward near the 30 th parallel of north latitude by way of Batang and Sitang to Tatsienlow, in the province of Szechwan, in West China, from which place their route was deflected at a right angle to Yunnan.

Considered in its general aspect, the flora of this region, as shown in the collection, is marked by the stunted form of the shrubs and dwarf character of the herbaceous vegetation. Of the forest trees, Coniferæ and others, no specimens were brought. It is characteristically a vegetation of high peaks, where drought and strong winds are the main climatic features. The Papaveraceæ are represented especially by dwarf, largeflowered kinds of Meconopsis. The greater number of the species of Corydalis are not more than two or three inches high. The Cruciferæ, such as Parrya ciliaris, in the same way are dwarf and large-flowered. Silene caspitosa may be compared with the most dwarf states of $S$. acaulis of our own high mountains. The honeysuckle of Tibet constitutes only a small bush about a foot high, with intertangled branches. But it is especially in the Rhododendrons and Primulas that this dwarf character is remarkable. All the Rhododendrons and Primulas found between Lhassa and Sitang-R. principis, $R$. primulceflorum, R. nigropunctatum, Primula leptopoda, $P$. diantha, and $P$. Henrici may be ranged amongst the dwarfest types of the genera to which they belong. It is the same with Incurvillea. The Tibetan species belong to a group found also in Kansu and Central Yunnan, with stem almost obliterated and corolla very large.

Passing eastward in Szechwan the flora puts on a different character. The leaves become larger, the number of flowers to each plant increases. There are many Rosaceæ, Orchids, and species of Pedicularis ; amongst the Compositæ the genus Senecio is particularly well represented, and there are several Everlastings that approach the Edelweiss of the Swiss Alps.

The flora of this eastern part of Tibet and western region of Szechwan has a strong affinity both with that of the Sikkim Himalaya and that of Central Yunnan. Meconopsis Henrici represents the Himalayan $M$. simplicifolia, Hook, et Thoms. Astragalus litargensis, A. acaulis, Benth., Rubus xanthocarpus, R. sikkimensis; Brachyactis chinensis, B. menthodora; Gnaphalizum corymbosum answers to $G$. nubigenum; Androsace bisulca to $A$. microphylla; and there are many other similar parallels between the plants of Tibet and Sikkim, and in the same many parallels may be found between the new species found by our travellers in Tibet and those gathered by Delavay in Yunnan.

\section{SOCIETIES AND ACADEMIES. LONDON.}

Royal Society, June 18.- "An Apparatus for testing the Sensitiveness of Safety-lamps." By Frank Clowes, D.Sc. Lond., Professor of Chemistry, University College, Nottingham. Communicated by Prof. Armstrong, F.R.S.

The following apparatus has been devised to render easy the NO. I I 33, VOL. 44$]$ process of testing the sensitiveness of different forms of safetylamps when used for detecting firedamp. To enable satisfactory tests to be made in the laboratory, it was necessary to insure (r) the easy and rapid production of mixtures of firedamp and air in known proportions; (2) to insure economy of the artificially prepared methane, which represented firedamp; and (3) to examine the flame of the lamp under conditions as satisfactory as those existing in the mine.

A wooden cubical box of about Ioo litres capacity was constructed so as to be as nearly gas-tight as possible. It was then made absolutely gas-tight by painting it over with melted paraffin wax, which was afterwards caused to penetrate more perfectly by passing an ordinary hot flat-iron over the surface.

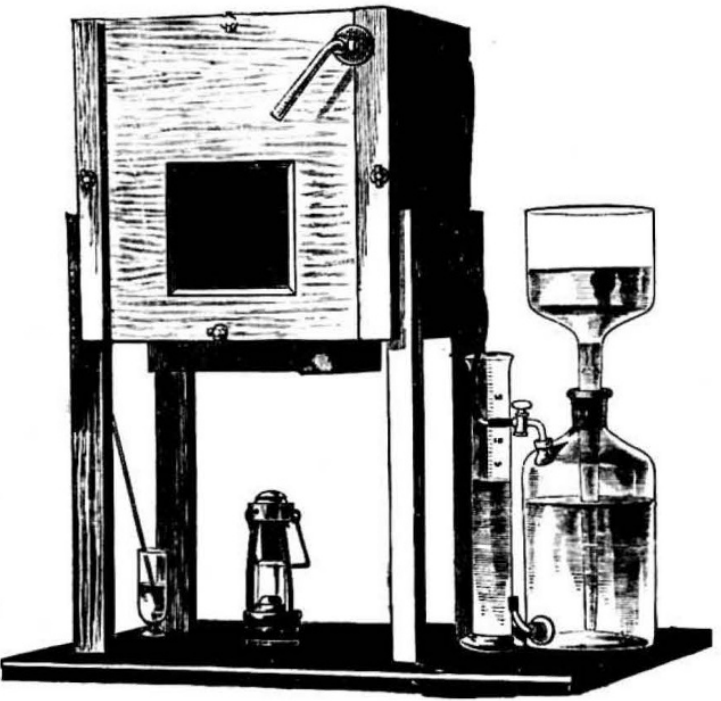

Fig. x.

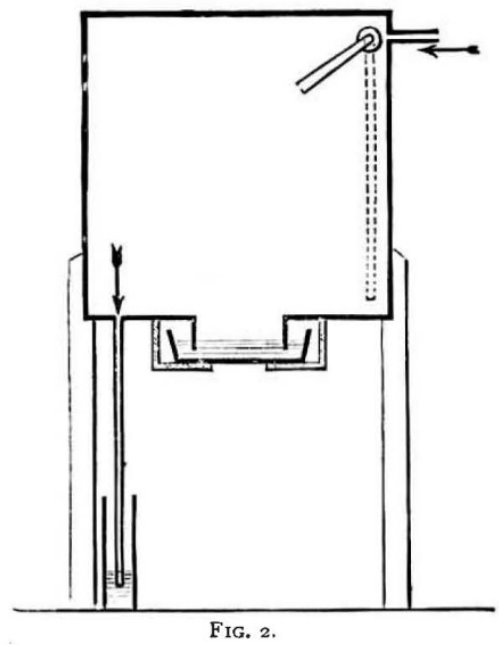

This testing chamber was furnished with a small inlet tube at the top, and with a similar outlet tube below. It had a plateglass window in front for observing the lamp in the interior, and a flanged opening below for introducing the safety-lamp. This opening was closed by a water-seal consisting of a small zinc tray supported by buttons, and containing about 2 inches depth of water, into which the flange dipped. A mixer was arranged, which consisted of a light flat board, nearly equal in dimensions to the section of the chamber, and suspended by an axis from the upper corner of the chamber. The mixer was moved rapidly backwards and forwards from the side to the top of the interior of the chamber, by grasping a handle projecting through the front of the chamber.

When a mixture of air with a certain definite precentage of 